\title{
Effects of Glazing Procedures on the Color Stability of Conventional and CAD/CAM Hybrid Ceramics: A Comparative Study
}

\section{Glaze İşlemlerinin Konvansiyonel ve CAD/CAM Hibrit Seramiklerin Renk Stabilizasyonunun Üzerine Etkisi: Karşılaştırmalı Çalışma}

\author{
Özgün Yusuf Özyılmaz ${ }^{1}$, Gülsüm Sayın Özel², Serra Bevek Oğuz Ahmet ${ }^{2}$
}

${ }^{1}$ Bezmialem Vakıf University Faculty of Dentistry, Department of Prosthodontic, istanbul, Turkey

${ }^{2}$ Istanbul Medipol University Faculty of Dentistry, Department of Prosthodontic, Istanbul, Turkey

Keywords

Ceramics, color stability, computer-aided design/computer-aided manufacturing, hybrid ceramic, nanoceramic

\section{Anahtar Kelimeler}

Seramikler, renk stabilizasyonu, bilgisayardestekli dizayn/bilgisayar- destekli üretim, hibrit seramik, nanoseramik

Received/Geliş Tarihi : 08.01.2019 Accepted/Kabul Tarihi : 29.01.2019

doi:10.4274/meandros.49369

Address for Correspondence/Yazışma Adresi: Özgün YusufÖzyıImaz MD,

Bezmialem Vakıf University Faculty of Dentistry, Department of Prosthodontic, İstanbul, Turkey

Phone : +90 5322800532

E-mail :oozyilmaz@bezmialem.edu.tr

(C) Meandros Medical and Dental Journal, Published by Galenos Publishing.

This is article distributed under the terms of the Creative Commons Attribution NonCommercial 4.0 International Licence (CC BY-NC 4.0).

\section{Abstract}

Objective: Ceramic glazing and polishing are important for patient satisfaction and long-term clinical success. Till date, no study has compared color changes after glazing procedures between conventional and more recently introduced ceramics. In this study; we investigated the effects of glazing procedures on the color stability of conventional and CAD/CAM hybrid ceramics using a spectrophotometer.

Materials and Methods: Eighty-four disc-shaped specimens were fabricated with seven different dental porcelain materials according to the manufacturers' instructions ( $n=12$ each): Ivoclar IPS DSign, Vita Omega 900, Ceramco III, Vita Mark II, Vita Enamic, GC Cerasmart, and Vita Suprinity. Both sides of the specimens were polished with wet $600-1000$ - and 1500-grit aluminium oxide abrasive papers, and color values ( $L^{*}, a^{*}$, $\left.b^{*}\right)$ were measured using a spectrophotometer before and after glazing. Treatmentinduced changes in the specimen color and topography were evaluated and recorded. The color change $(\Delta E)$ was calculated from the changes in the mean $L^{*}, a^{*}$, and $b^{*}$ values. All data were analyzed using Kruskal-Wallis, Mann-Whitney $U$, and Wilcoxon tests (95\% confidence level).

Results: Color changes were below the clinically perceptible level $\left(\Delta \mathrm{E}_{1}<3.7\right)$ in all specimens. Color change values after the glazing procedures were $2.27 \pm 0.55,2.99$ $\pm 0.67,1.01 \pm 0.58,1.62 \pm 0.70,0.74 \pm 0.45,1.35 \pm 0.52$, and $1.37 \pm 0.72$ for Ivoclar IPS DSign, Vita Omega 900, Ceramco III, Vita Mark II, GC Cerasmart, Vita Enamic, and Vita Suprinity, respectively; thus, there were significant differences between the conventional and CAD/CAM ceramics $(p<0.05)$. The conventional ceramic Vita Omega 900 presented the least color stability, while the CAD/CAM ceramic GC Cerasmart presented the maximum color stability.

Conclusions: Glazing procedures do not cause evident changes in the color of conventional and CAD/CAM hybrid ceramics, although the color stability of the latter is better than that of the former.

Öz

Amaç: Seramik glaze ve parlatma işlemleri hasta memnuniyeti ve uzun süreli klinik başarı için önemlidir. Bugüne kadar hiçbir çalışma, geleneksel ve daha yeni tanıtılan seramikler arasındaki glaze işlemlerinden sonra renk değişimlerini karşılaştırmamıştır. Bu çalışmada glaze prosedürlerinin bir spektrofotometre kullanarak geleneksel ve CAD/ CAM hibrit seramiklerin renk stabilitesi üzerindeki etkilerini araştırılmıştır. 
Gereç ve Yöntemler: Üretici firma talimatlarına göre seksen-dört disk şeklindeki örnekten yedi farklı porselen malzemesi ile üretildi ( $n=12)$ : Ivoclar IPS DSign, Vita Omega 900, Ceramco III, Vita Mark II, Vita Enamic, GC Cerasmart ve Vita Suprinity. Numunelerin her iki tarafı 600-, 1000- ve 1500-grit alüminyum oksit aşındırıcı kağıtlarla aşındırılmış ve glaze işleminden önce ve sonra bir spektrofotometre kullanılarak renk değerleri $\left(L^{*}, a^{*}, b^{*}\right)$ ölçülmüştür. Örneklerin rengindeki ve topografisindeki tedaviye bağlı değişiklikler değerlendirildi ve kaydedildi. Renk değişimi $(\Delta E)$, ortalama $L^{*}, a^{*}$ ve $b$ * değerlerindeki değişikliklerden hesaplandı. Tüm veriler Kruskal-Wallis, Mann-Whitney U ve Wilcoxon testleri kullanılarak analiz edildi (\% 95 güven aralığı).

Bulgular: Renk değişiklikleri tüm örneklerde klinik olarak algılanabilir seviyenin $\left(\Delta E_{1}<3.7\right)$ altındaydı. Glaze işlemlerinden sonra renk değişimi değerleri sırasıyla Ivoclar IPS DSign, Vita Omega 900, Ceramco III, Vita Mark II, GC Cerasmart, Vita Enamic ve Vita Suprinity için $2.27 \pm 0.55,2.99 \pm 0.67,1.01 \pm 0.58,1.62 \pm 0.70,0.74 \pm 0.45,1.35 \pm 0.52$ ve $1.37 \pm 0.72$ olarak bulundu; bu nedenle, konvansiyonel ve CAD/CAM seramikleri arasında önemli farklılıklar vardı ( $p<0.05)$. Geleneksel seramik Vita Omega 900 en düşük renk stabilitesini sunarken, CAD/CAM seramik GC Cerasmart maksimum renk stabilitesini sundu.

Sonuç: Glaze prosedürleri, konvansiyonel ve CAD/CAM hibrit seramiklerin renginde belirgin değişikliklere neden olmamakla birlikte, işlem sonrasının renk stabilitesi öncekinden daha iyidir.

\section{Introduction}

The goal of ceramic restorations in the anterior dentition is to achieve acceptable esthetics by reproduction of the morphological, biological, and optical features of the lost tooth structure. Although several studies have demonstrated exceptional color stability for different ceramic systems, clinicians have reported difficulties in replication of the actual tooth color and shade matching with the surrounding dentition (1). Reproduction of the translucency and color of the natural teeth is one of the most important factors affecting the esthetic value of a dental ceramic restoration. The color of all-ceramic restorations is influenced by the type, thickness, surface texture, and shape of the ceramic material; number of firings; and firing temperatures (2). The elements of color, such as hue, value, and chroma; translucency and opacity; light transmission and scattering; and metamerism and fluorescence, are the main factors affecting the optical properties of a restoration. Among these, the "value" level is of paramount importance for achieving a vital, lifelike appearance that is in harmony with the surrounding dentition (3).

The Commission Internationale de I'Eclairage (CIE) $\mathrm{L}^{*} \mathrm{a}{ }^{*} \mathrm{~b}^{*}$ color space was defined by the International Commission on Illumination, and it expresses color as three numerical values, where $L^{*}$ represents the lightness component and $a^{*}$ and $b^{*}$ represent the green-red and blue-yellow color components, respectively. $\Delta \mathrm{E}$ used to designate the color changes in terms of these parameters (4). If the $\Delta E$ value is $>1$, the color variation can be visually observed by $50 \%$ human observers, while a color difference represented by a $\Delta \mathrm{E}$ value of $>2$ can be perceived by $100 \%$ observers
(5). However, for oral restorations, a $\Delta E$ value of $\leq 3.7$ is clinically acceptable because of uncontrolled factors within and around the oral cavity. The $L^{*}$ axis gives the coordinates of lightness and darkness, and these coordinates change between 0 (extremely dark) and 100 (extremely light). A decrease in the $a^{*}$ value represents a decrease in redness, while a decrease in the $b *$ value represents a decrease in yellowness (6).

of late, CAD/CAM materials are being used for nearly all type of restorations because of advantages such as biocompatibility, durability, and esthetics; decreased chairside time; shorter manufacturing time; and lower cost (7). CAD/CAM materials are categorized as polymer-infiltrated ceramics and resin nanoceramics according to their contents, with both types having some advantages. Materials with increased resin content are soft and compliant and cause less damage to the antagonist teeth while demonstrating high wear resistance because of the presence of nano or macroparticules and use of finishing and polishing procedures. In comparison, materials with higher ceramic content exhibit greater wear resistance, improved esthetic outcomes, more biocompatiblility, and lesser discoloration $(7,8)$. Recently, CAD/CAM-fabricated, high-load capacity hybrid ceramics combining ceramic and glass polymers were developed. An example is Vita Enamic (Vita Zahnfabrik H. Rauter, Bad Säckingen, Germany), which comprises $86 \%$ ceramic and $14 \%$ polymer by weight. Another currently employed CAD/CAM material is GC Cerasmart (GC Corparation, Tokyo, Japan), which comprises $71 \%$ ceramic and barium glass nanoparticles by weight and is based on nanotechnology (9). In addition, Vita Suprinity (Vita 
Zahnfabrik H. Rauter, Bad Säckingen, Germany), a zirconia-reinforced lithium silicate ceramic containing 8\%-12\% zirconium oxide, $56 \%-64 \%$ silicone dioxide, and $15 \%-21 \%$ lithium oxide, has been used because of its high strength $(10,11)$.

A rougher surface after finishing procedures may cause several problems such as plaque accumulation, discoloration, and secondary caries due to bacterial adhesion. Polishing procedures provide a smooth surface and irregularities measuring smaller than bacterial diameters; this should reduce plaque accumulation $(12,13)$. Surface roughness can also cause antagonist tooth abrasion and decreased fracture resistance of the material due tosurface microcracks (14), and polishing or smoothening the surface can maximize the bend stength and minimize the risk of fractures and cracks (15). Therefore glazing and polishing or smoothening procedures are important for patient satisfaction and longterm clinical success. Various glazing techniques for improving the material strength by covering surface flaws after the manufacturing process are available for both conventional and CAD/CAM ceramics (14). Although several studies have evaluated color changes after repeated firings of ceramic materials (16-18), only a few have evaluated the optical properties of recently introduced hybrid ceramics and nanoceramics $(19,20)$. Furthermore, no study has compared color changes after glazing procedures between conventional ceramics and newer hybrid ceramics. The purpose of this in vitro study was to evaluate the effects of glazing procedures on the color stability of conventional and CAD/CAM hybrid ceramics using a spectrophotometer. The null hypothesis was that that there are no significant differences between these ceramic types in terms of color changes after glazing procedures.

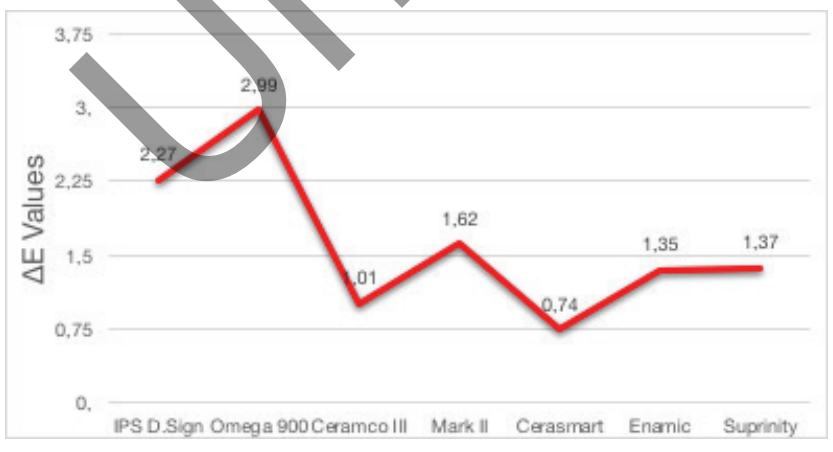

Figure 1. $\Delta \mathrm{E}$ values of materials

\section{Materials and Methods}

In total, 84 disc-shaped specimens (12-mm diameter and 2-mm thickness) were fabricated from the following seven dental ceramic materials: Ivoclar IPS DSign (Ivoclar Vivadent AG, Schaan, Liechtenstein), Vita Omega 900 (Vita Zahnfabrik H. Rauter, Bad Säckingen, Germany), Ceramco III (Ceramco-Dentsply, Burlington, NJ, USA), Vita Suprinity, Vita Mark II (Vita Zahnfabrik H. Rauter, Bad Säckingen, Germany), Vita Enamic, and GC Cerasmart ( $n=12$ per material). The properties, manufacturers, and firing and glazing temperatures for these materials are shown in Table 1.

For specimen preparation from the three conventional dental ceramics, namely Ivoclar IPS DSign, Vita Omega 900, and Ceramco III, a specially prepared teflon mold with the dimensions of the specimens was used. For each material, the powder and liquid were mixed on a clean glass surface and condensed into the teflon mold after isolation. After vibration, moist areas from the superior surfaces were removed using paper napkins. Porcelain dough

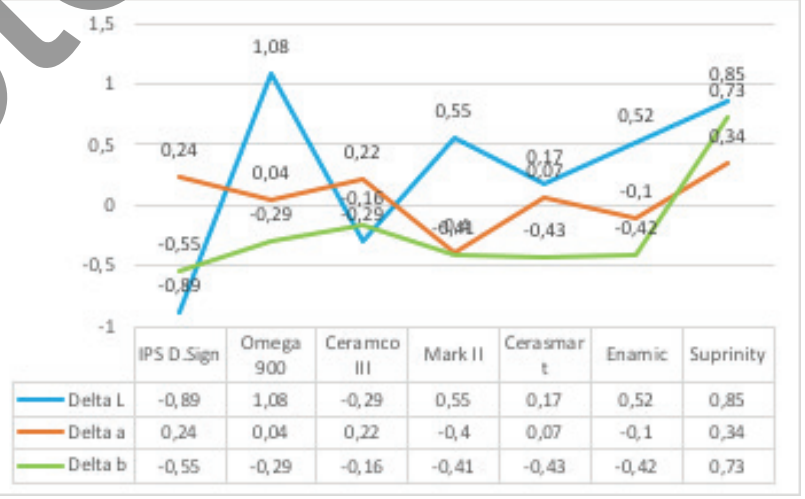

Figure 2. $\Delta \mathrm{L}$ (blue), $\Delta \mathrm{a}$ (orange), $\Delta \mathrm{b}$ (green) values of materials

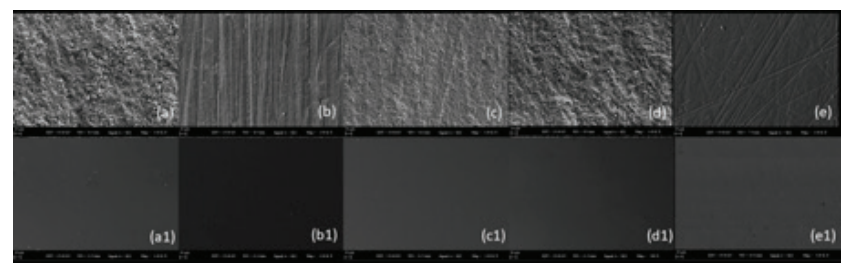

Figure 3. SEM images of ceramic surfaces (1000x), a) unglazed vita omega 900 b) unglazed gc cerasmart c) unglazed vita enamic d) unglazed vita mark ii e) unglazed vita suprinity a1) glazed vita omega 900 b1) glazed gc cerasmart c1) glazed vita enamic d1) glazed vita mark ii e1) glazed vita suprinity 


\begin{tabular}{|c|c|c|c|c|c|c|c|}
\hline $\begin{array}{l}\text { Product } \\
\text { name }\end{array}$ & Type of the Ceramic & $\begin{array}{l}\text { Condensing } \\
\text { method }\end{array}$ & Manufacturer & \multicolumn{2}{|c|}{ Firing Temp/ Time } & Glazing Type & $\begin{array}{l}\text { Glazing Temp/ } \\
\text { Time }\end{array}$ \\
\hline $\begin{array}{l}\text { Ivoclar IPS } \\
\text { D Sign }\end{array}$ & $\begin{array}{l}\text { Metal-ceramic } \\
\text { porcelain } \\
\text { (Flouroapatite leucite } \\
\text { glass-ceramic) }\end{array}$ & $\begin{array}{l}\text { Powder/ } \\
\text { Liquid }\end{array}$ & $\begin{array}{l}\text { Ivoclar Vivaden } \\
\text { Schaan, Liechte }\end{array}$ & $\begin{array}{l}\text { AG, } \\
\text { stein }\end{array}$ & $\begin{array}{l}403-870^{\circ} \mathrm{C} \\
60^{\circ} \mathrm{C} / \mathrm{min} . \\
8 \mathrm{~min} .+\mathrm{VAC}\end{array}$ & $\begin{array}{l}\text { Glazewith } \\
\text { temp }\end{array}$ & $\begin{array}{l}403-870^{\circ} \mathrm{C} \\
60^{\circ} \mathrm{C} / \mathrm{min} . \\
5 \mathrm{~min} .+\mathrm{VAC}\end{array}$ \\
\hline $\begin{array}{l}\text { Vita Omega } \\
900\end{array}$ & $\begin{array}{l}\text { Metal-ceramic } \\
\text { porcelain(Leucite } \\
\text { crystalline glass- } \\
\text { ceramic) } \\
\end{array}$ & $\begin{array}{l}\text { Powder/ } \\
\text { Liquid }\end{array}$ & $\begin{array}{l}\text { Vita Zahnfabrik } \\
\text { Bad Säckingen, }\end{array}$ & $\begin{array}{l}\text { H. Rauter, } \\
\text { jermany }\end{array}$ & $\begin{array}{l}600-900^{\circ} \mathrm{C} \\
50^{\circ} \mathrm{C} / \mathrm{min} . \\
13 \mathrm{~min} .+\mathrm{VAC}\end{array}$ & $\begin{array}{l}\text { Glaze with } \\
\text { temp }\end{array}$ & $\begin{array}{l}600-900^{\circ} \mathrm{C} \\
75^{\circ} \mathrm{C} / \mathrm{min} .\end{array}$ \\
\hline Ceramco III & $\begin{array}{l}\text { Metal-ceramic } \\
\text { porcelain (Feldspatic } \\
\text { Porcelain) }\end{array}$ & $\begin{array}{l}\text { Powder/ } \\
\text { Liquid }\end{array}$ & $\begin{array}{l}\text { Ceramco-Dents } \\
\text { Burlington, NJ, }\end{array}$ & $\begin{array}{l}\text { ly, } \\
\text { SA }\end{array}$ & $\begin{array}{l}650-960^{\circ} \mathrm{C} \\
55^{\circ} \mathrm{C} / \mathrm{min} . \\
10 \mathrm{~min} .+\mathrm{VAC}\end{array}$ & $\begin{array}{l}\text { Gla } \\
\text { tem }\end{array}$ & $\begin{array}{l}650-945^{\circ} \mathrm{C} \\
70^{\circ} \mathrm{C} / \mathrm{min} \text {. } \\
\text {-VAC. }\end{array}$ \\
\hline Vita Mark II & $\begin{array}{l}\text { Feldspar Ceramic } \\
\text { Blocks }\end{array}$ & $\begin{array}{l}\text { Cad-Cam } \\
\text { Blocks }\end{array}$ & $\begin{array}{l}\text { Vita Zahnfabrik } \\
\text { Bad Säckingen, }\end{array}$ & $\begin{array}{l}\text { Rauter, } \\
\text { ermany }\end{array}$ & $\begin{array}{l}\text { CAD, } \\
\text { Milli }\end{array}$ & $\begin{array}{l}\text { Glaze with } \\
\text { temp }\end{array}$ & $\begin{array}{l}\text { VITAAKZENT } \\
\text { Glaze spray } 850 \\
{ }^{\circ} \mathrm{C}\end{array}$ \\
\hline Vita Enamic & Hibrit dental ceramic & $\begin{array}{l}\text { Cad-Cam } \\
\text { Blocks }\end{array}$ & $\begin{array}{l}\text { Vita Zahnfabrik } \\
\text { Bad Säckingen, }\end{array}$ & $\begin{array}{l}\text { H. Rauter, } \\
\text { Germany }\end{array}$ & $\begin{array}{l}\text { CAD/CAM } \\
\text { Milling }\end{array}$ & $\begin{array}{l}\text { Glazing Liquid } \\
\text { with Light } \\
\text { Polimerization }\end{array}$ & $\begin{array}{l}\text { VITA ENAMIC } \\
\text { Glaze light cure } \\
30-60 \mathrm{sec} . / \mathrm{min} \\
405 \mathrm{~nm}\end{array}$ \\
\hline $\begin{array}{l}\text { GC } \\
\text { Cerasmart }\end{array}$ & Hybrid nanoceramic & $\begin{array}{l}\text { Cad-Cam } \\
\text { Blocks }\end{array}$ & $\begin{array}{l}\text { GC Corpa } \\
\text { Japan }\end{array}$ & & $\begin{array}{l}\text { CAD/CAM } \\
\text { Milling }\end{array}$ & $\begin{array}{l}\text { Glazing Liquid } \\
\text { with Light } \\
\text { Polimerization }\end{array}$ & $\begin{array}{l}\text { OPTIGLAZE } \\
\text { light cure } \\
30-60 \mathrm{sec} . / \mathrm{min} \\
405 \mathrm{~nm}\end{array}$ \\
\hline $\begin{array}{l}\text { Vita } \\
\text { Suprınity }\end{array}$ & $\begin{array}{l}\text { Zirconia reinforced } \\
\text { glass ceramic }\end{array}$ & $\begin{array}{l}\text { Cad-Cam } \\
\text { Blocks }\end{array}$ & $\begin{array}{l}\text { Vita Zahnfabrik } \\
\text { Bad Säckingen, }\end{array}$ & $\begin{array}{l}\text { H. Rauter, } \\
\text { Germany }\end{array}$ & $\begin{array}{l}\text { CAD/CAM } \\
\text { Milling } \\
400-840 o C \\
550 C / m i n . \\
15 \mathrm{~min}+V A C\end{array}$ & $\begin{array}{l}\text { Glaze with } \\
\text { Temp. }\end{array}$ & $\begin{array}{l}\text { VITA AKZENT } \\
\text { Glaze spray } 850 \\
\text { oC }\end{array}$ \\
\hline
\end{tabular}

samples made from $(12 \times 2 \mathrm{~mm})$ thick asbestos sheets baked in vacuum in a ceramic furnace(Austromat3001, DEKEMA DentalKeramiköfen $\mathrm{GmbH}$, Freilassing, Germany) accordance with the instructions.

For Vita Mark II, Vita Enamic, and GC Cerasmart, disc-shaped specimens $(12 \times 2 \mathrm{~mm})$ were designed by a software programme (Autodesk Inc., CA, USA) and milled with the 5-axes imes-icore 550i (3Shape $A / S$, Copenhagen, Denmark). Unlike the other three CAD/CAM ceramics, Vita Suprinity specimens needed sintering, so the initially designed dimensions were kept slightly larger than $12 \times 2 \mathrm{~mm}$. The specimens were heated in a furnace with a step sintering procedure involving sintering at $950^{\circ} \mathrm{C}$ for $10 \mathrm{~min}$ and $1500^{\circ} \mathrm{C}$ for $2 \mathrm{~h}$. After sintering, the thickness was adjusted and the final thickness of each specimen was measured using a digital micrometer (Digimatic Indicator 0001-2; Mitutoyo). The final dimensions of all specimens were $12 \times 2 \mathrm{~mm}$.
To obtain standardized and plane surfaces that allowed appropriate specimen positioning for color change measurements, both sides of the ceramic specimens were polished with wet 600-, 1000-, 1500grit aluminum oxide abrasive papers under running water using the Metaserve2000 polishing machine (Buehler UK Ltd. Coventry, West Midlands, England). All specimens were glazed with their own natural glazing materials (Table 1 ) and ultrasonically cleaned in distilled water for $5 \mathrm{~min}$ before testing.

\section{Color Change Measurements}

A spectrophotometer (VITA Easyshade ${ }^{\circledR}$, Germany) was used to record L*, a*, and $b^{*}$ values. The specimens were rinsed with water and dried, following which a trained examiner recorded the color values using the spectrophotometer against a white background in standardized D65 daylight. The spectrophotometer was calibrated using the calibration plate according to the manufacturer's instructions. All measurements 
were performed before and after the glazing procedures. Three readings were recorded for each specimen, and the average value was calculated. Changes in each parameter were measured as $\Delta \mathrm{L}$, $\Delta a$, and $\Delta b$ by a single investigator, and the overall color change $(\Delta \mathrm{E})$ was calculated using the following equation (21):

$$
\Delta \mathrm{E}=[(\Delta \mathrm{L}) 2+(\Delta \mathrm{a}) 2+(\Delta \mathrm{b}) 2] 1 / 2
$$

\section{Scanning Electron Microscopy}

One representative specimen with a $\Delta \mathrm{E}$ value closest to the mean value was selected from each group for scanning electron microscopy (SEM) studies. Each specimen was ultrasonically rinsed in water for 10 min, dehydrated for 1 week, mounted on retainers, coated with a 20-nm layer of gold-palladium alloy, and examined under a scanning electron microscope (Jeol JSM 6400, Tokyo, Japan) for the evaluation of surface morphological changes. Photomicrographs of representative areas were taken at a magnification of $1000 \times$.

\section{Statistical Analysis}

All statistical analyses were performed using SPSS version 20 (IBM Corp., New York, USA). The parameters were tested for normal distribution using the Kolmogorov-Smirnov test. In accordance with a $p$-value of $<0.05$ as per Levene's test, intergroup differences in $\Delta E$ values were evaluated using the Kruskal-Wallis test, with the Mann-Whitney $U$ test used to determine the group causing a difference. The Wilcoxon signed rank test was used for within-group comparisons. A p-value of $<0.05$ was considered statistically significant.

\section{Results}

Each color parameter $\left(L^{*}, a^{*}, b^{*}\right)$ and color change value $(\Delta \mathrm{E})$ for the tested materials are shown in Table 2. According to the Wilcoxon test, there were statistically significant differences within groups ( $p<$ 0.05). In the IPSDSign and Ceramco III groups, both a* and $b^{*}$ values were significantly different before and after the glazing procedures $(p<0.05)$. For Vita Mark II, there was a statistically significant difference in the a* value, whereas the GC Cerasmart and Vita Enamic groups showed significant differences in the $b^{*}$ value. In the Suprinity group, $L^{*}, a^{*}$, and $b^{*}$ values showed significant differences before and after the glazing procedures. On the other hand, none of the values for Omega 900 showed a significant difference.

According to Kruskal-Wallis and Mann-Whitney U tests, the color changes in all materials were clinically acceptable, with a $\Delta E$ value of $<3.7$. The $\Delta E$ values for the conventional ceramics, i.e., Ceramco III (1.01 $\pm 0.58)$, IPS DSign ( $2.27 \pm 0.55)$, and Vita Omega 900 (2.99 \pm 0.67$)$, were significantly higher than those for the CAD/CAM ceramics, i.e., GC Cerasmart (0.74 \pm $0.45)$, Vita Enamic (1.35 \pm 0.52$)$, Vita Suprinity (1.37 $\pm 0.72)$, and Vita Mark II (1.62 \pm 0.70$)$. GC Cerasmart

\begin{tabular}{|c|c|c|c|c|c|c|c|c|c|c|c|}
\hline \multicolumn{2}{|r|}{$\Delta \mathrm{E}$} & \multicolumn{3}{|c|}{$\begin{array}{c}\Delta \mathrm{L} \\
\mathrm{L} 1-\mathrm{L} 2\end{array}$} & \multicolumn{3}{|c|}{$\begin{array}{c}\Delta \mathrm{a} \\
\mathrm{a} 1-\mathrm{a} 2\end{array}$} & \multicolumn{3}{|c|}{$\begin{array}{c}\Delta b \\
b 1-b 2\end{array}$} & \multirow[b]{2}{*}{$p$ values } \\
\hline & Mean & $\begin{array}{l}\text { Std. } \\
\text { Dev }\end{array}$ & Mean & $\begin{array}{l}\text { Std } \\
\text { Dev }\end{array}$ & $p$ values & Mean & Std Dev & $p$ values & Mean & Std Dev & \\
\hline IPS D.Sign & 2,2 & 0,55 & $-0,89^{a}$ & 0,27 & 0.224 & $0,24^{\mathrm{a}}$ & 0,07 & 0.002 & $-0,55^{a}$ & 0,36 & 0.002 \\
\hline Omega 900 & 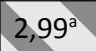 & 0,67 & $1,08^{b}$ & 0,67 & 0.182 & $0,04^{\mathrm{ab}}$ & 0,11 & 0.196 & $-0,29^{a}$ & 0,70 & 0.168 \\
\hline Ceramco III & $1,01^{\mathrm{bc}}$ & 0,58 & $-0,29^{a}$ & 0,19 & 0.116 & $0,22^{a}$ & 0,12 & 0.003 & $-0,16^{a}$ & 0,16 & 0.011 \\
\hline Mark II & $1,62^{\mathrm{abc}}$ & 0,70 & $0,55^{b}$ & 0,29 & 0.136 & $-0,40^{c}$ & 0,48 & 0.027 & $-0,41^{a}$ & 0,87 & 0.116 \\
\hline Cerasmart & $0,74^{c}$ & 0,45 & $0,17^{b}$ & 0,34 & 0.124 & $0,07^{\mathrm{ab}}$ & 0,19 & 0.204 & $-0,43^{a}$ & 0,65 & 0.046 \\
\hline Enamic & $1,35^{b c}$ & 0,52 & $0,52^{b}$ & 0,24 & 0.131 & $-0,10^{b c}$ & 0,30 & 0.167 & $-0,42^{a}$ & 0,35 & 0.005 \\
\hline Suprinity & $1,37^{\mathrm{bc}}$ & 0,72 & $0,85^{b}$ & 0,48 & 0.002 & $0,34^{a}$ & 0,21 & 0.003 & $0,73^{b}$ & 0,83 & 0.019 \\
\hline$p$ values & 0.000 & & 0.001 & & & 0.000 & & & 0.000 & & \\
\hline
\end{tabular}


showed the maximum color stability among all the tested materials.

\section{Discussion}

In the present study, we found significant differences among conventional and CAD/CAM ceramics with regard to the color stability after glazing procedures. While the conventional ceramic Omega 900 presented the least color stability, the CAD/CAM ceramic GC Cerasmart presented the maximum color stability. Thus, the null hypothesis was rejected.

With regard to $L^{*}$ values, the color of all materials tended to be on the darker side after glazing, with positive $\Delta \mathrm{L}$ values for all materials except Ips Dsign and Ceramco III. Similarly, Yilmaz et al. reported negative $\Delta L$ values for IPS Dsign and Ceramco III, attributing the increased lightness to opacification, decrystallization, and devitrification after multiple firings (17). However, in the present study, differences in $L^{*}$ values before and after glazing were not significant for any material except Vita Suprinity, which showed a significant increase in darkness that was probably caused by recrystallization and vitrification due to the presence of zirconium oxide. The CAD/CAM ceramic GC Cerasmart presented the lowest $\Delta \mathrm{L}$ value, although the difference was not significant.

With regard to a* values, IPS DSign, Ceramco IH, and Vita Suprinity showed significant decreases after glazing, which indicated an increase in the green component. On the other hand, significant increases in a* values for Vita Mark II and Vita Enamic indicated an increase in the red component. All materials except Vita Suprinity showed increased $b^{*}$ values, which indicated an increase in the yellow component, although the increase was not significant for Vita Mark II. The $b^{*}$ value for Vita Suprinity, a zirconia-reinforced lithium disilicate glass ceramic, showed a significant decrease, probably because of the presence of metal oxide.

All tested ceramics in the present study showed a $\Delta \mathrm{E}$ value of $>3.7$; therefore, the color changes after glazing were in the clinically acceptable range. Although Vita Suprinity contains $8 \%-12 \%$ zirconium oxide, the $\Delta \mathrm{E}$ value was significantly lower than those for IPS DSign and Omega 900. Among the conventional ceramics, Omega 900 showed a significantly higher $\Delta \mathrm{E}$ value than did Ceramco III, probably because of differences in $\Delta$ a values between the two materials. In fact, Omega 900 showed the maximum color change that was clinically perceivable by the human eye $(\Delta E$ $>2.7$ ) (5).

Among the CAD/CAM ceramics, Vita Mark II showed a high $\triangle \mathrm{E}$ value that was comparable with the value for Omega 900, while GC Cerasmart showed the lowest $\Delta \mathrm{E}$ value. Moreover, Vita Suprinity showed significant changes in all three color parameters ( $\mathrm{L}^{*}$, $\left.a^{*}, b^{*}\right)$ after glazing.

In the present study, firing was performed only once for the comparison of color changes after glazing procedures between conventional veneer ceramics and polymer-infiltrated hybrid ceramics. Heffman et al. investigated color changes during firing and reported significant changes during the initial firing, with less distinct changes during subsequent firings. This means that the first firing is clinically more significant than subsequent firings (22). Our results supported the findings of previous studies reporting that repeated firings up to nine times did not noticeably affect the color stability of any tested shade $(23,24)$.

The CIE L*a*b* color system is commonly used for color research and serves as the gold standard for research in dentistry worldwide (25). Visual color observations are the result of physiological and psychological responses to radiant energy stimulation (26), and several uncontrolled factors can result in altered perception of color. Conversely, instrumental measurements can quantify color and allow more uniform and precise interpretations (27).

Colorimeters are more economic and convenient devices when compared with other devices such as spectrophotometers (28). However, these devices have small apertures, and a considerable fraction of the light entering the assessed material is lost because it emerges on the surface outside the measurement aperture. This loss of light is termed edge-loss and could be a cause of color measurement errors (29). In particular, edge-loss may occur with translucent materials and when the diameter of the evaluated material is smaller than the aperture of the colorimeter (18). Our findings may differ from clinical color measurements because of the in vitro study design and specimen shape. However, the geometry of disc-shaped specimens is generally adequate for the measurement of surface smoothness and color changes (17). 
In 2014, Gómez-Polo et al. (28) published that there is no clear opinion regarding the correlation between the human eye and a spectrophotometer with regard to tooth shade determination. A spectrophotometer excludes the subjective mistakes of a human observer. However, Chu et al. stated that instrumental and visual shade matching methods should be combined (29). In the present in-vitro study, the background for color assessments was always uniformly white, considering that different backgrounds can affect the $\Delta \mathrm{E}$ value (30). Instrumental color analysis offers a potential advantage over visual color determination because instrumental readings are objective, can be quantified, and are more rapidly obtained (31). Spectrophotometers are among the most accurate, useful, and flexible instruments for color matching. They function by measuring the spectral reflectance or transmittance curve of a specimen and are useful for surface color measurements (32). Because the use of a colorimeter results in edge-loss, we used the VITA Easyshade ${ }^{\circledR}$ guide spectrophotometer in the present study.

Çelik et al. (33) pointed out that disc-shaped specimens provide more accurate results than do crown-shaped specimens. Accordingly, we used discshaped specimens in the present study. When light falls on a rough and irregular surface, it irregularly reflects and diffuses, resulting in a color change (30). Kim et al. (34) found that the texture of the surface affected the $L^{*}$ value, which is lower for a glazed surface (seen as white) than for a polished surface. Other studies also showed that the surface texture affects light reflection and results in variations in the $L^{*}$ value $(30,34)$ The SEM findings in the present study supported our results in terms of the the surface texture.

The microstructure of hybrid ceramics is different from that of conventional dental porcelains, although both types have a large proportion of crystalline particles. Heffernan et al. reported that the quantity of transmitted and emerged light, in comparison with the wavelength of light, depends on the amount, chemical structure, and size of crystalline particles in the matrix of the material (31). Moreover, Yilmaz et al. reported that Empress E-max and Empress II ceramics presented color change values different from those for conventional ceramics because of the high crystalline content (17). We observed similar results in the present study comparing CAD/CAM hybrid ceramics and conventional powder-liquid ceramics. The differences in our study can be attributed to the effect of the crystalline particles in the ceramic matrix and their chemical composition on the wavelength of the reflected light.

Several studies have suggested that certain metal oxides do not show color stability after being subjected to firing temperatures, and that surface colorants demonstrate pigment breakdown at firing temperatures (35). Furthermore, the $\Delta \mathrm{E}$ values for ceramics containing zirconium oxide increase, although not beyond 3.7 (36). Barghi (37) reported that slight changes in color after multiple firings may be attributed to the increase in density caused by the decrease in air bubbles trapped within the porcelain. Porcelain exhibits high viscosity at low liquid temperatures, and this impairs the diffusion of ionic species in the molten glassy phase. In the present study, Ceramco III showed the lowest $\Delta \mathrm{E}$ value among the conventional ceramics. The other tested ceramics, Omega 900 and IPS DSign, contain a large proportion of crystalline leucite particles. Therefore, greater color changes may have occurred because of damage to the surface of the ceramic structure caused by repeated exposure of the dense crystalline structure to high temperatures. Moreover, greater color changes may have been observed for IPS DSign and Omega 900 because, as mentioned above, the quantity of the transmitted and emerged light depends on the crystalline particles in the matrix (31). We also observed that the $\triangle E$ values for the CAD/ CAM ceramics were significantly lower than those for the conventional ceramics, probably because conventional ceramics require mixing of powder and liquid and are less dense than CAD/CAM ceramics, which are relatively more homogenous and dense. Among the CAD/CAM ceramics, Vita Mark II, which exhibits a high feldspar ceramic content along with 20\%-23\% aluminium oxide, and Vita Suprinity, which contains lithium disilicate with $8 \%-12 \%$ zirconium oxide, showed high $\Delta E$ values. This can be attributed to the glazing procedure, high temperature exposure, and the high crystalline content. Moreover, the presence of metal oxide in the Vita Suprinity may have resulted in the increased color change. Yilmaz et al. reported that high firing temperatures were required for ceramics containing leucite and lithium 
disilicate. Continuous and/or high-temperature firings of these porcelains caused pyroclastic flow with surface accumulation. The disc-shaped specimens lost their contours and recrystallization occurred, which consequently led to color changes exceeding the clinically acceptable range (17) Vita Suprunity has a high lithium disilicate content while IPS DSign and Omega 900 have a high leucite content, and this may have resulted in the high $\Delta \mathrm{E}$ values for these materials in the present study.

Shürmann and Olms reported that the hybrid ceramics Vita Enamic and Lava Ultimate showed better shade stability than did Vita Mark II after immersion in different stain solutions for 120 days (38). Both Vita Mark II and Vita Suprinity showed higher $\Delta \mathrm{E}$ values than did Vita Enamic and GC Cerasmart, probably because of differences in the inorganic particle content, glazing procedures, and metal oxide content. Both Vita Enamic and GC Cerasmart undergo glazing with a special liquid and at a lower temperature, which results in lesser color changes for these materials.

Tekce et al. studied the effects of glazing (with Optiglaze) on three CAD/CAM hybrid ceramics, namely Vita Enamic, GC Cerasmart, and Lava Ultimate. The authors reported that glazed surfaces were more advanced and smoother than were unglazed surfaces.20 In our study, we used a special glazing liquid and a light-cured nanofilled glazing system for Vita Enamic (Vita Enamic Glaze Liquid) and GC Cerasmart (Optiglaze), respectively, according to the manufacturers reccomendations. As a result of these nonthermal glazing procedures, both these materials showed low $\triangle E$ values, with GC Cerasmart showing the lowest value among all seven tested materials. This finding is consistent with that of Sahin et al., who reported smooth and color-stable surfaces after 3000 thermocyles for specimens treated with Optiglaze (39).

Cetindemir et al. evaluated the effect of light sources and CAD/CAM monolithic blocks on the degree of conversion (DC) of cement, which is associated with the translucency of CAD/CAM materials (10). They reported significantly different DC values for GC Cerasmart and Vita Enamic, which have similar filler profiles and organic and inorganic contents, and explained that this difference was caused by the nanoparticle and aluminum contents. The translucency of all-ceramic restorations increases with the particle size. The pores in hybrid ceramics are filled with polymer resin. Resin matrix and nanoceramic particles bond to each other with strong cross-linking, and pores filled with nanoparticles in the ceramic matrix result in a homogenous structure. Nanoceramics have nanoparticles, whereas hybrid ceramics have macroparticles. Hybrid ceramics also contain $20 \%-23 \%$ aluminum, whereas nanoceramics have no aluminum content. These differences may be responsible for the greater color changes in Vita Enamic than in GC Cerasmart in the present study.

This study has some limitations. First, the surface roughness of the ceramics and its effects on their color stability were not investigated. Second, the dyeability of the materials was not considered. Third, thermal cycling was not applied to the specimens. Fourth, there was no saliva layer because of the in vitro design. Further studies overcoming these limitations are necessary to further clarify our findings.

\section{Conclusion}

Within the study limitations, the findings suggest that glazing procedures do not affect the color stability of conventional and CAD/CAM hybrid ceramics to a clinically significant extent. However, the color stability of glazed CAD/CAM hybrid ceramics is better than that of glazed conventional veneer ceramics.

\section{Ethics}

Ethics Committee Approval: The ethics committee approval was not necessary since the study was in vitro.

Informed Consent:

Peer-review:

\section{Authorship Contributions}

Concept: O.Y.O., G.S.O., Design: O.Y.O., G.S.O., Data Collection or Processing: G.S.O., B.S.A.O., Analysis or Interpretation: O.Y.O., Literature Search: G.S.O., Writing: O.Y.O., G.S.O., B.S.A.O.

Conflict of Interest: No conflict of interest was declared by the authors.

Financial Disclosure: The authors declared that this study received no financial support.

\section{References}

1. Jarad FD, Russell MD, Moss BW. The use of digital imaging for color matching and communication in restorative dentistry. $\mathrm{Br}$ Dent J 2005; 199:43-9 
2. Uludag B, Usumez A, Sahin V, Eser K, Ercoban E. The effect of ceramic thickness and number of firings on the colour of ceramic systems: An in vitro study. J Prosthet Dent 2007;97:25-31

3. Pizzamiglio E. A color selection technique. J Prosthet Dent 1991;66: 592-6

4. Johnston WM, Kao EC. Assessment of appearance match by visual observation and clinical colorimetry. J Dent Res 1989; 68:819-22

5. Seghi RR, Hewlett ER, Kim J. Visual and instrumental colorimetric assessments of small color differences on translucent dental porcelain. J Dent Res 1989;68:1760-4

6. Berns RS. Billmeyer and Saltzman's principles of colour technology. 3rd ed. New York: John Wiley \& Sons; 2000. p. 71-4

7. Russe ND, Sadoun MJ. Resin-composite blocks for dental CAD/ CAM applications. J Dent Res 2014;93:1232-4

8. Blatz MB. Long-term clinical success of all-ceramic posterior restorations. Quintessence Int 2002;33:415-26

9. Cekic-Nagas I, Ergun G, Egilmez F, Vallittu PK, Lassila LV. Microshear bond strength of different resin cements to ceramic/ glass-polymer CAD-CAM block materials. J Prosthodont Res 2016;60:265-73

10. Cetindemir AB, Sermet $B$, Ongul D. The effect of light sources and CAD/CAM monolithic blocks on degree of conversion of cement. J Adv Prosthodont 2018; 10(4), 291-9

11. Riquieri H, Monteiro JB, Viegas DC, Campos TMB, de Melo RM, de Siqueira FASG. Impact of crystallization firing process on the microstructure and flexural strength of zirconia-reinforced lithium silicate glass-ceramics. Dent Mater 2018;34(10), 148391.

12. Yilmaz C, Korkmaz T, Demirkoprulu H, Ergun G, Ozkan Y. Color stability of glazed and polished dental porcelains.J Prosthodont 2008;17:20-4.

13. Ikeda M, Matin K, Nikaido T, Foxton RM, Tagami J. Effect of surface characteristics on adherence of S. mutans biofilms to indirect resin composites. Dent Mater J 2007;26:915-23

14. de Jager N, Feilzer AJ, Davidson CL. The influence of surface roughness on porcelain strength. Dent Mater 2000;16:381-8.

15. Fischer $H$, Schäfer $M$, Marx R. Effect of surface roughness on flexural strength of veneer ceramics. J Dent Res 2003;82: 972-5

16. Pires-de-Souza FCP, Casemiro LA, Garcia LFR, Cruvinel DR. Colour stability o dental ceramics submitted to artificial accelerated ageing after repeated firings.J Prosthet Dent, 2009;101:13-8

17. Yilmaz K, Gonuldas F, Ozturk C. The effect of repeated firings on the color change of dental ceramics using different glazing methods. J Adv Prosthodont, 2014;6:427-33

18. Yilmaz B, Ozcelik TB, Wee AG. Effect of repeated firings on the color of opaque porcelain applied on different dental alloys. J Prosthet Dent 2009 101(6):395-404

19. Acar O, Yilmaz B, Altintas SH, Chandrasekaran I, Johnston WM. Color stainability of CAD/CAM and nanocomposite resin materials. J Prosthet Dent 2016;115(1):71-5

20. Tekçe N, Fidan S, Tuncer S, Kara D, Demirci M. The effect of glazing and aging on the surface properties of CAD/CAM resin blocks. J Adv Prosthodont 2018;10(1): 50-7
21. Nguyen C, Augros C, Rocca JP, Lagori G, Fornaini. KTP AND Er:YAG laser dental bleaching comparison: a spectrophotometric, thermal and morphologic analysis. Laser Med Sci 2015;8:215764

22. Heffernan MJ, Aquilino SA, Diaz-Arnold AM, Haselton DR, Stanford CM, Vargas MA. Relative translucency of six all-ceramic systems. Part II: core and veneer materials. J Prosthet Dent 2002;88:10-5

23. Berns RS. Billmeyer and Saltzman's principlesof color technology. 3rd ed. New York:John Wiley \& Sons; 2000. p. 71-4

24. Rosenstiel SF, Land MF, Fujimoto J. Contemporary fixed prosthodontics. 4th ed. St Louis: Elsevier; 2006. p. 709-39, 740-3

25. van der Burgt TP, ten Bosch JJ, Borsboom PC, Kortsmit WJ. A comparison of new and conventional methods for quantification of tooth color. J Prosthet Dent 1990;63:155-62

26. Seghi RR, Johnston WM, O'Brien WJ. Performance assessment of colorimetric devices on dental porcelains. J Dent Res 1989;68:1755-9

27. Bolt RA, Bosch JJ, Coops JC. Influence of window size in smallwindow colour measurement, particularly of teeth.Phys Med Biol 1994;39:1133-42.

28. Gómez-Polo C, Gómez-Polo M, Celemin-Viñuela A, Martínez Vázquez De Parga JA, De Parga V. Differences between the human eye and the spectrophotometer in the shade matching of tooth colour. J Dent 2014; 42(6): 742-5.

29. Chu SJ, Trushkowsky RD, Paravina RD. Dental color matching instruments and systems. Review of clinical and research aspects. J Dent 2010; 38(2): 2-16

30. Lee YK, Lim BS, Kim CW. Effect of surface conditions on the color of dental resin composites. J Biomed Mater Res 2002;63:657-63

31. Heffernan MJ, Aquilino SA, Diaz-Arnold AM, Haselton DR, Stanford CM, Vargas MA. Relative translucency of six all-ceramic systems. Part I: core materials. J Prosthet Dent 2002; 88:4-9.

32. O'Brien WJ, Kay KS, Boenke KM, Groh CL. Sources of color variation on firing porcelain. Dent Mater 1991;7:170-3

33. Celik G, Uludag B, Usumez A, Sahin V, Ozturk O, Goktug G. The effect of repeated firings on the color of an all-ceramic system with two different veneering porcelain shades. J Prosthet Dent 2008;99:203-8

34. Kim IJ, Lee YK, Lim BS, Kim CW. Effect of surface topography on the color of dental porcelain. J Mater Sci Mater Med 2003;14:405-9

35. O'Brien WJ, Kay KS, Boenke KM, Groh CL. Sources of color variation on firing porcelain. Dent Mater 1991;7:170-3

36. Alharbi A, Ardu S, Bortolotto T, Krejci I. Stain susceptibility of composite and ceramic CAD/CAM blocks versus direct resin composites with different resinous matrices. Odontology 2017; 105(2): 162-9

37. Barghi N. Color and glaze: effects of repeated firings. J Prosthet Dent 1982;47:393-5

38. Schürmann MG and Olms C. Shade Stability of Polymer-Infiltrated and Resin Nano Ceramics. Open Dent J 2018, 18;12:791-800

39. Sahin O, Dede DO, Koroglu A, Yılmaz B. Influence of surface sealant agents on the surface roughness and color stability of artificial teeth. J Prosthet Dent 2015;114:130-7 